\title{
Fundamental Parameters Affecting Non Linearity of Suspension Bridges
}

\author{
Dr,Ahmed Gasim ${ }^{(*)}$ And Haitham A.A.Elboushi ${ }^{(* *)}$
}

\begin{abstract}
In this research factors affecting the non-linearity of suspension bridges were studied. The fundamental parameters studied are the main and side span lengths, cable sag, tower height, cable $x$-section and the flexural rigidity of the stiffening girder. The effect of variation of each parameter on the cable tension and the girder moments is studied.

A non-linear 2-dimensional mathematical model of a 3 span, continuous suspension bridge is considered. The solution is based on the second order deflection theory given in a computerized form. It has been found that the degree of effect of these parameters on the results of analysis in a descending order is: the main span length, side span length, cable sag, cable section and the stiffness of the bridge girder.
\end{abstract}

ملخص - - مل

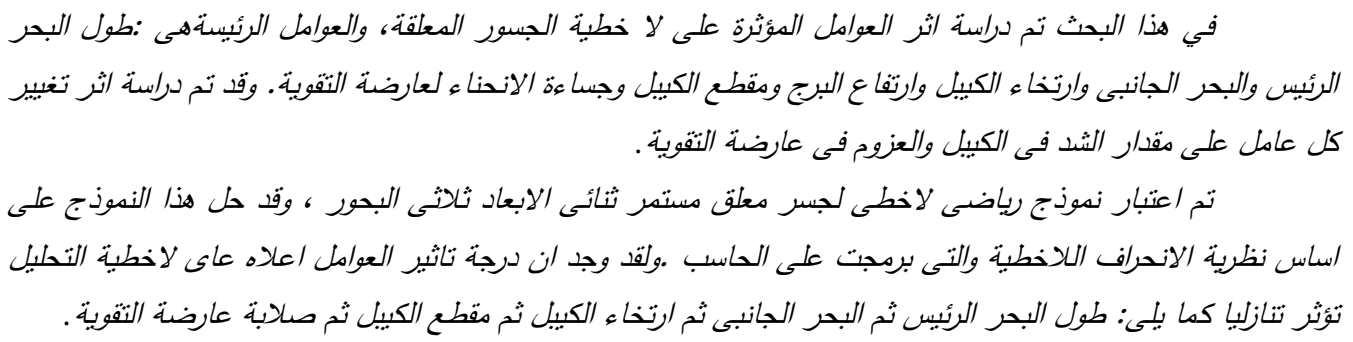

* Assistant Prof. , Fac. Of Eng. Sciences, Omdurman Islamic University.

** Lecturer; Fac. Of Eng., Sudan University of Science and Technology.

\section{Introduction}


Cable structures ${ }^{(1)}$, have been known to undergo large deformations due to their flexibility. This is termed geometric non-linearity which require special analysis. Among those cable structures, externally-anchored Suspension Bridges are mostly affected by non-linearity. The major suspension bridge elements are shown in Fig. (1).

Historically ${ }^{(2)}$, suspension bridges analysis passed through several developments. The main theories and their features are as follows :

(A) Rankine theory: An old theory originated by Rankine in 1885 .The theory assumed that the applied live load on the bridge deck will be uniformly resisted by equal hangers tension. Of course this is an approximate theory yielding inaccurate results .

(B) The Elastic theory: considers the cable as an inverted arch . It is common and approximate and yields too high values of bending moments and shears in the girder. The theory does not consider the effect of change of cable geometry.

(C) The Deflection theory: a more exact method, which takes account of deformed configuration of the structure. The theory was originated by Melan in 1888, extended by Moisseff and Steinman for continuous suspension bridges; and then generalized by Steiman in $1935^{(3,4)}$. The theory can be summarized as follows.

\section{The Deflection Theory ${ }^{(2,3,4,5,6,7,8)}$}

\section{a-General}

Analysis of suspension bridges by the deflection theory is based on nonlinear formulation and provides appropriate provision for the influence of deflections in changing the geometry. The theory is based on the differential equation of the cable and the stiffening girder, together with the cable equation, which governs the elastic extension of the cable and the shortening arising from the deflection along the cable.

\section{b- Basic Assumptions}

(1) The initial curve of the cable is a parabola.

(2) The initial dead load, w, is carried by the cable only, producing the initial horizontal tension, $\mathrm{H}$.

(3) Suspenders elongations are negligible 
(4 The deflection of any point on the cable, $\mathrm{v}(\mathrm{x})$, due to applied live load "p" per unit length of the girder, is sensible .

\section{c- Fundamental Equations}

The bending moment at any point of a simple suspended span is given by ${ }^{(10)}$ :

$$
M=M_{0}-h y
$$

Where $\mathrm{h}$ is the induced tension due to live load.

. For amount of deflection $\mathrm{v}$, the bending moment will be reduced to

$$
M=\left[M_{0}-h y\right]-(H+h) v
$$

For a continuous suspended middle span, accounting for continuity, equation (2) will take the form

$$
M=\left[M_{0}-h y\right]-(H+h) v+T
$$

where $\mathrm{T}$, is the continuity moment and is given by

$$
\mathrm{T}=\mathrm{T}_{1}-\frac{\left(\mathrm{T}_{1}+\mathrm{T}_{2}\right)}{\mathrm{L}} \mathrm{x}
$$

It can been proven that ${ }^{(10)}$

$$
H=\frac{w L^{2}}{8 d}
$$

Denoting

$$
\mathrm{C}^{2}=\frac{\mathrm{H}+\mathrm{h}}{\mathrm{EI}}
$$

and, since $M=-E I v^{\prime \prime}$, equation (3) becomes

$$
v^{\prime \prime}=C^{2} v-\frac{C^{2}}{H+h}\left(M_{0}+T-h y\right)
$$

Equation (7) is the first fundamental equation; known as the girder equation. There are two unknowns; namely the deflection $\mathrm{v}$ and the induced tension " $h$ ". The other fundamental equation, known as the cable equation is ${ }^{(2,3,9)}$ :

$$
\frac{h l}{A_{c} E_{c}} \pm \propto L_{c} t-\frac{w}{H} \int_{0}^{L} v d x=0
$$

in which

$$
l=\int_{0}^{L}\left(\frac{d s}{d x}\right)^{3} d x \approx L\left(\sec ^{3} \theta+8 \frac{d^{2}}{L^{2}} \sec \theta\right)
$$


and

$$
L_{c}=\int_{0}^{L}\left(\frac{d s}{d x}\right)^{2} d x \approx L\left(\sec ^{2} \theta+\frac{16}{3} \frac{d^{2}}{L^{2}}\right)
$$

The solution of equation (7) will yield the general formula for girder deflection

$$
v=\frac{h}{h+H}\left[C_{1} e^{C x}+C_{2} e^{-C x}+\left(\frac{M_{0}}{h}+\frac{T}{h}-y\right)+\frac{1}{C^{2}}\left(\frac{8 d}{L^{2}}-\frac{p}{h}\right)\right]
$$

where $\mathrm{C}_{1}$ and $\mathrm{C}_{2}$ are integration constants.

\section{d- Solution of Analytical Model by the Deflection Theory}

In this section, the general 2-dimensional, 3-span, continuous suspension bridge model, shown in Fig. (2) is solved, on the basis of the deflection theory. The application of equation, (7), to any span of the model necessitates the evaluation of the followings:

i) Three pairs of the integration constants $C_{1}$ and $C_{2}$ for the three span segments $\mathrm{k}, \mathrm{m}$, and $\mathrm{j}$; and this is done by applying boundary conditions.

ii) The girder continuity moments $T_{1}$ and $\left(-T_{2}\right)$ at the towers; the continuity of the slopes at the towers is used here.

iii) The horizontal component of the induced tension (h) due to live loads; the cable equation is used here.

It will be shown hereafter that the above parameters (which are twenty one parameters for the entire bridge ) are interdependent, i.e. every set of the parameters is a function of the other two sets. To overcome such complexity, an iterative computerized analysis is developed as follows.

\section{e- Determination of Moments, Shears, Deflection \& Suspenders' Tension}

Referring to equation (11), the girder deflection at any point $\mathrm{x}$ on any span $\mathrm{i}$, of length $\mathrm{L}_{\mathrm{i}}$, is given by:-

$$
v_{i}(x)=\frac{h}{h+H}\left[C_{1} e^{C_{i} x}+C_{2} e^{-C_{i} x}+\left(\frac{M_{0 i}}{h}+\frac{T}{h}-y_{i}\right)-\frac{1}{C_{i}^{2}}\left(\frac{p_{x}}{h}-\frac{8 d_{i}}{L_{i}^{2}}\right]\right.
$$

Differentiating eq. (12) with respect to $\mathrm{x}$ will give the slope of the girder: 


$$
v_{i}^{\prime}(x)=\frac{C_{i} h}{h+H}\left[C_{1} e^{C_{i} x}-C_{2} e^{-C_{i} x}+\frac{1}{C_{i}}\left(\frac{M_{0 i}^{\prime}}{h}+\frac{T^{\prime}}{h}-y_{i}^{\prime}\right)\right]
$$

But $\quad M=-E I v^{\prime \prime}$, and so the moment at any section $\mathrm{x}$ is

$$
M_{i}(x)=-h\left[C_{1} e^{C_{i} x}+C_{2} e^{-C_{i} x}+\frac{1}{C_{i}^{2}}\left(\frac{8 d_{i}}{L_{i}^{2}}-\frac{p_{x}}{h}\right)\right]
$$

The shear is

$$
V=\frac{d M}{d x}
$$

Substituting

$$
\left.V_{i}(x)=-C_{i} h \mid C_{1} e^{C_{i} x}-C_{2} e^{-C_{i} x}\right\rfloor
$$

The portion of the live load carried by the suspenders per unit length, $\mathrm{q}(\mathrm{x})$, is the difference between the live load at the section $\mathrm{p}_{\mathrm{x}}$ and the net load carried by the girder, i.e.

$$
q(x)=p_{x}-\left(-\frac{d V}{d x}\right)=p_{x}-C_{i}^{2} h\left[C_{1} e^{C_{i} x}+C_{2} e^{-C_{i} x}\right]
$$

\section{f- Computer Implementation of The solution Based on the Deflection Theory $^{(10)}$ :}

The foregoing analysis based on the deflection theory is implemented in computer form here. An iterative algorithm to determine the value of $h$ satisfying all equation is followed. The FORTRAN computer program written is named as SASDEF (static Analysis of suspension bridges using the Deflection theory). Two subroutines serve the main program:

(1) SUBROUTINE CIC2: for calculation of the integration constants sets $\mathrm{C}_{1}, \mathrm{C}_{2}$.

(2) SUBROUTINE CONT: for calculation of the continuity moments of the girder at the towers.

Few entries are needed, and the program reveals a complete solution to the girder- cable interaction of the bridge, see flow chart, Fig.(3).

\section{g- Effect of Fundamental Parameters}

Data Information of an Existing Suspension Bridge: 
In this chapter using the computer program for the second order theory for a real data bridge (Innoshima, Japan at 1983, with m3ain span $770 \mathrm{~m})^{(11)}$, the parameter information data of this bridge can be organized as below:

Table (1): The Information Data of Innoshima Bridge

\begin{tabular}{|l|c|c|}
\hline \multicolumn{1}{|c|}{ Description } & Abbreviation & Value \\
\hline Main span & $\mathrm{L}$ & $770 \mathrm{~m}$ \\
\hline Side span & $\mathrm{L}_{1}$ & $250 \mathrm{~m}$ \\
\hline Sag & $\mathrm{D}$ & $76 \mathrm{~m}$ \\
\hline Tower height & $\mathrm{DD}$ & $130 \mathrm{~m}$ \\
\hline Area of girder & $\mathrm{AG}$ & $1.5 \mathrm{~m}^{2}$ \\
\hline Cable section & $\mathrm{AC}$ & $0.4562 \mathrm{~m}^{2}$ \\
\hline $2^{\text {nd }}{ }_{\text {moment } \text { of inertia of girder }}$ & $\mathrm{I}$ & $4.904 \mathrm{~m}^{4}$ \\
\hline Modulus of girder elasticity & $\mathrm{E}$ & $2.06 \mathrm{E} 8 \mathrm{~N} / \mathrm{mm}^{2}$ \\
\hline Modulus of cable elasticity & Ec & $1.962 \mathrm{E} 8 \mathrm{~N} / \mathrm{mm}^{2}$ \\
\hline Initial thermal degree & $\mathrm{TH}_{1}$ & $27.747 \mathrm{c}^{\circ}$ \\
\hline
\end{tabular}

Table (2) Live Load Data of Innoshima Bridge (assumed):

\begin{tabular}{|c|c|c|}
\hline Description & Abbreviation & Value \\
\hline Load Rite side span & $\mathrm{P}$ & $29.6 \mathrm{kN} / \mathrm{m}$ \\
\hline
\end{tabular}


مجلة العلوم الهندسية_العدد الثاني-2006

\begin{tabular}{|l|c|c|}
\hline Segment no.1 Right side & S1=J1/L1 & 1.0 \\
\hline Segment no.2 Right side & T1=K1/L1 & 0.0 \\
\hline Load at main span & P1 & $29.6 \mathrm{kN} / \mathrm{m}$ \\
\hline Spacing no.1 at left main span & S2=J2/L & 1.0 \\
\hline Spacing no.2 at left main span & T2=K2/L1 & 0.0 \\
\hline Load at left side span & P2 & $29.6 \mathrm{kN} / \mathrm{m}$ \\
\hline Spacing no.1 at left main span & S3=J3/L & 1.0 \\
\hline Spacing no.2 at left main span & T3=K3/L1 & 0.0 \\
\hline
\end{tabular}

\section{Trial Data}

Using a fixed variation for each parameter by $10 \%$ the trial data assumed in the study is as shown Table (3), It can be recognized that the original data lie with in the trail data. The objective of these variations is to observe their influence on the non - linearity of the analysis performed by the deflection theory.

Table (3)

\begin{tabular}{|c|l|c|c|c|c|c|c|c|c|c|}
\hline \multicolumn{2}{|c|}{ Main parameters } & Notations & $\begin{array}{c}\text { Original } \\
\text { data }\end{array}$ & $\begin{array}{c}\text { Rate of } \\
\text { variation }\end{array}$ & \multicolumn{5}{|c|}{ Trial data which are applied in the study } \\
\hline 1 & Main span (m) & L & 770 & $10 \%$ & 500 & 550 & 605 & 665 & 732.05 & 805.25 \\
\hline 2 & $\begin{array}{l}\text { Side span length } \\
\text { (m) }\end{array}$ & L1 & 250 & $10 \%$ & 200 & 220 & 242 & 266.2 & 292.85 & 322.10 \\
\hline 3 & Sag Depth (m) & D & 76 & $10 \%$ & 60 & 66 & 72.6 & 79.86 & 87.846 & 96.630 \\
\hline 4 & Tower height (m) & DD & 130 & $10 \%$ & 100 & 110 & 121 & 133.1 & 146.41 & 161.05 \\
\hline 5 & I of Girder $\left(\mathrm{m}^{4}\right)$ & I & 4904 & $10 \%$ & 4000 & 4400 & 4840 & 5324 & 5856.4 & 6442.0 \\
\hline 6 & Cable section $\left(\mathrm{m}^{2}\right)$ & Ac & 0.456 & $10 \%$ & 0.35 & 0.385 & 0.4235 & 0.4658 & 0.5124 & 0.5636 \\
\hline
\end{tabular}

On selecting a trial value of any parameter, we run the program to obtain the results for that parameter in-terms of:

1. Max +ve BM in girder (kN.m).

2. Max-ve BM in girder (kN.m).

3. Max shear $(\mathrm{kN})$.

4. Max deflection at mid span ,(m). 
5. Max deflection at site $\operatorname{span},(\mathrm{m})$.

6. Horizontal component $(\mathrm{H})$ of the cable Tension due to D.L, $(\mathrm{kN})$.

7. Horizontal component (h) of the cable Tension due to L.L, $(\mathrm{kN})$.

\section{Results}

Analysis of the results of original dimension of the bridge is illustrated in Table (4).

Table (4)

\begin{tabular}{|c|c|}
\hline Results: & values \\
\hline Max +ve BM in girder $(\mathrm{kN} . \mathrm{m})$ & 155061.9876 \\
\hline Max -ve BM in girder $(\mathrm{kN.m})$ & 203107.3234 \\
\hline Max shear $(\mathrm{kN})$ & 7141.1411 \\
\hline Max deflection at mid span (m) & 1.520418 \\
\hline Max deflection at side span (m) & 1.464713 \\
\hline Horizontal component(H) of cable Tension (KN) due to D.L & $0.1950329 \mathrm{E}+06$ \\
\hline Horizontal component(h) of cable Tension (KN) due to L.L & 26325.49189 \\
\hline
\end{tabular}

Analysis results for each parameter variation are shown in Table (5) To Table (9).

Table (5) Effect of main span length (L) on the Non-linear analysis (With constant side span length)

\begin{tabular}{|c|c|c|c|c|c|c|c|}
\hline $\mathbf{A}$ & main span (m) & 500 & 550 & 605 & 665 & 732.05 & 805.255 \\
\hline 1 & Max +ve BM in girder (kN.m) & 29067.2 & 54376.0 & 82491.7 & 111687.7 & 140945.5 & 168176.0 \\
\hline 2 & Max -ve BM in girder (kN.m) & -70558.55 & -101630.80 & -132882.60 & -162786.00 & -190727.50 & -214608.00 \\
\hline 3 & Max shear $(\mathrm{kN})$ & 1716.91000 & 2733.62100 & 3876.32900 & 5112.24500 & 6440.02800 & 7792.46500 \\
\hline 4 & Max deflection at mid span (m) & -0.65928 & -0.84510 & -1.02148 & -1.19887 & -1.39767 & -1.63445 \\
\hline 5 & Max deflection at side span (m) & 0.51515 & 0.73422 & 0.95511 & 1.16875 & 1.37212 & 1.55073 \\
\hline 6 & $\begin{array}{c}\text { Horizontal component(H) of } \\
\text { cable Tension }(\mathrm{KN}) \text { due to } \mathrm{D.L}\end{array}$ & 82236.84 & 99506.58 & 120403.00 & 145468.80 & 176257.90 & 213166.10 \\
\hline 7 & $\begin{array}{l}\text { Horizontal component(h) of cable } \\
\text { Tension }(\mathrm{KN}) \text { due to L.L }\end{array}$ & 11475.07525 & 13937.40320 & 16849.51550 & 20201.56000 & 24085.77461 & 28395.36100 \\
\hline
\end{tabular}


Table (6) Effect of side span length (L1) on the Non-linear analysis (With constant side span length)

\begin{tabular}{|c|c|c|c|c|c|c|c|}
\hline B & side span length $(\mathrm{m})$ & 200 & 220 & 242 & 266.2 & 292.85 & 322.102 \\
\hline 1 & Max +ve BM in girder $(\mathrm{kN} . \mathrm{m})$ & 401078.5 & 290293.7 & 188484.1 & 97245.8 & 16929.1 & 15421.9 \\
\hline 2 & Max -ve BM in girder $(\mathrm{kN} . \mathrm{m})$ & -496392.0 & -357609.9 & -239752.2 & -141432.7 & -57974.3 & -56100.8 \\
\hline 3 & Max shear $(\mathrm{kN})$ & 20128.06000 & 13747.76000 & 8650.25400 & 4629.66400 & 1389.18200 & 1172.90200 \\
\hline 4 & Max deflection at mid span $(\mathrm{m})$ & -1.48058400 & -1.53751900 & -1.53712800 & -1.44868900 & -1.23436100 & 0.08427160 \\
\hline 5 & Max deflection at side span $(\mathrm{m})$ & 2.22962 & 1.95978 & 1.60825 & 1.17011 & 0.61010 & -0.09718 \\
\hline 6 & $\begin{array}{c}\text { Horizontal component(H) of } \\
\text { cable Tension }(\mathrm{KN}) \text { due to } \mathrm{D} . \mathrm{L}\end{array}$ & 195032.90 & 195032.90 & 195032.90 & 195032.90 & 195032.90 & 195032.90 \\
\hline 7 & $\begin{array}{c}\text { Horizontal component(h) of cable } \\
\text { Tension }(\mathrm{KN}) \text { due to L.L. }\end{array}$ & 29805.27111 & 28098.75337 & 26711.64153 & 25735.08118 & 25262.23770 & 25478.10000 \\
\hline
\end{tabular}

Table (7) Effect of sag span length (D) on the Non-linear analysis

\begin{tabular}{|c|c|c|c|c|c|c|c|}
\hline C & sag length $(\mathrm{m})$ & 60 & 66 & 72.6 & 79.86 & 87.846 & 96.6306 \\
\hline 1 & Max + ve BM in girder (kN.m) & 154267.3 & 157791.8 & 157272.2 & 153344.0 & 146543.2 & 137567.8 \\
\hline 2 & Max -ve BM in girder (kN.m) & -212203.8 & -211334.2 & -207108.7 & -199920.7 & -190230.2 & -178497.7 \\
\hline 3 & Max shear $(\mathrm{kN})$ & 7779.43900 & 7627.36200 & 7337.56900 & 6940.67000 & 6463.56300 & 5932.99800 \\
\hline 4 & Max deflection at mid span (m) & 1.028997 & 1.077286 & 1.117544 & 1.1503261 & 1.19657 & 1.21657 \\
\hline 5 & Max defiection at side span (m) & 1.54119 & 1.52492 & 1.48585 & 1.42695 & 1.35166 & 1.26322 \\
\hline 6 & $\begin{array}{c}\text { Horizontal component }(\mathrm{H}) \text { of } \\
\text { cabie Tension }(\mathrm{KN}) \text { due to } \mathrm{D} . \mathrm{L} \\
\end{array}$ & 247041.70 & 224583.30 & 204166.70 & 185606.10 & 168732.80 & 153393.40 \\
\hline 7 & $\begin{array}{c}\text { Horizontal component(h) of cable } \\
\text { Tension (KN) due to L.L }\end{array}$ & 29879.25558 & 28600.00890 & 27100.59889 & 25458.73673 & 23742.27536 & 22007.52656 \\
\hline
\end{tabular}

Table (8): Effect of Cable x-section on the analysis 


\begin{tabular}{|c|c|c|c|c|c|c|c|}
\hline D & Cable section & 0.35 & 0.385 & 0.4235 & 0.46585 & 0.512435 & 0.5636785 \\
\hline 1 & Max +ve BM in girder $(\mathrm{kN} . \mathrm{m})$ & 136977.7 & 144029.8 & 150853.0 & 157145.8 & 162976.2 & 168510.9 \\
\hline 2 & Max -ve BM in girder $(\mathrm{kN} \cdot \mathrm{m})$ & -196411.4 & -199322.9 & -202020.1 & -204534.1 & -206870.1 & -209027.5 \\
\hline 3 & Max shear $(\mathrm{kN})$ & 6649.08200 & 6841.50900 & 7025.22000 & 7195.36800 & 7353.28100 & 7501.96400 \\
\hline 4 & Max deflection at mid span $(\mathrm{m})$ & 1.103561 & 1.11253 & 1.125576 & 1.136512 & 1.14612 & 1.15521 \\
\hline 5 & Max deflection at side span $(\mathrm{m})$ & 1.41463 & 1.43209 & 1.44806 & 1.46299 & 1.47689 & 1.48962 \\
\hline 6 & $\begin{array}{c}\text { Horizontal component( } \mathrm{H}) \text { of } \\
\text { cable Tension }(\mathrm{KN}) \text { due to D.L }\end{array}$ & 195032.90 & 195032.90 & 195032.90 & 195032.90 & 195032.90 & 195032.90 \\
\hline 7 & $\begin{array}{c}\text { Horizontal component( } \mathrm{h}) \text { of cable } \\
\text { Tension }(\mathrm{KN}) \text { due to L.L }\end{array}$ & 25459.55580 & 25789.95558 & 26099.15448 & 26387.04748 & 26654.69555 & 26903.53526 \\
\hline
\end{tabular}

Table (9) : Effect of girder rigidity on the analysis

\begin{tabular}{|c|c|c|c|c|c|c|c|}
\hline $\mathbf{E}$ & $\begin{array}{c}\text { Second moment of } \\
\text { inertia of the girder }\end{array}$ & 4000 & 4400 & 4840 & 5324 & 5856.4 & 6442.04 \\
\hline 1 & Max +ve BM in girder $(\mathrm{kN} . \mathrm{m})$ & 143751.1 & 149341.7 & 155174.4 & 160790.2 & 166487.2 & 172244.3 \\
\hline 2 & Max -ve BM in girder $(\mathrm{kN} . \mathrm{m})$ & -203829.8 & -203922.6 & -203979.3 & -204027.3 & -204040.4 & -204014.7 \\
\hline 3 & Max shear $(\mathrm{kN})$ & 6935.348 & 7039.435 & 7147.169 & 7250.769 & 7355.104 & 7459.697 \\
\hline 4 & Max deflection at mid span $(\mathrm{m})$ & 1.1253 & 1.131605 & 1.13412 & 1.13746 & 1.138212 & 1.140125 \\
\hline 5 & Max deflection at side span $(\mathrm{m})$ & 1.467134 & 1.46385 & 1.460114 & 1.456465 & 1.45249 & 1.448172 \\
\hline 6 & $\begin{array}{c}\text { Horizontal component }(\mathrm{H}) \text { of } \\
\text { cable Tension }(\mathrm{KN}) \text { due to } \mathrm{D} . \mathrm{L}\end{array}$ & 195032.90 & 195032.90 & 195032.90 & 195032.90 & 195032.90 & 195032.90 \\
\hline 7 & $\begin{array}{c}\text { Horizontal component(h) of cable } \\
\text { Tension }(\mathrm{KN}) \text { due to } \mathrm{L} . \mathrm{L}\end{array}$ & 26196.54238 & 26257.76509 & 26317.98886 & 26375.35446 & 26430.3171 & 26482.3056 \\
\hline
\end{tabular}

\section{Plotting the Relation between Each Parameter and its Effects on the Analysis}

The preceding results (Table 5 to Table 9) are illustrated in graphical from- as shown in appendix (I), so as to observe the relation between each parameter variations and the corresponding effect on the main result analysis, namely; Max. . +ve BM in girder, Max -ve BM in girder, Max. shear in the girder, Max. deflection at mid span, Max. deflection at side span and the horizontal component $(\mathrm{H})$ of cable Tension . Every chart equation is written to its best fit with regression type of polynomial trend.

\section{Conclusions}


مجلة العلوم الهندسية_العدد الثنان-2006

The foregoing research explains how the non-linearity based on the computerized treatment of the deflection theory affects the analysis of suspension bridges. The effect of several parameters on the results analysis is studied by varying each parameter and observing the result variation. The following conclusions are derived .

a. Increasing the main span length causes the rate of change of several results of analysis to decrease, namely: maximum positive bending moment in the main span girder, maximum negative bending moment in the girder, maximum shear in the girder, maximum deflection in the mid span girder and max deflection at side span girder.

b. Increasing the main span length will increase the rate of increase of cable tension .This result is very important-design wise-because it proves that as the main span length increase, more load is being carried by the cable. Consequently suspenders tensions becomes now significant.

c. Increasing the side span length generally will increase the rate of decrease of some results analysis namely: maximum positive bending moment in the girder, maximum negative bending moment in the girder, maximum shear in the girder , maximum deflection at the mid span girder and max deflection at side span girder. It can be noticed that as the side span length approaches or exceeds half the value of the main span, the rate of change vanishes.

d. Increasing of the side span length will cause the cable tension to decrease. This relation is valid just before the side span length approaches half the main span length, after witch the cable tension will increase.

e. The deformation findings prove that optimum design length of the side span is a value of approximately half the main span length.

f. The effect of sag on the analysis results is less than of the main span and side spans lengths.

g. Effects of cable cross-section and the moment of inertia of the stiffening girder are not significant as shown on graphs . 
h. In general it can be concluded that as the externally-anchored suspension bridges spans increase, the whole structure becomes stiffer .And the cable system will carry more addition loads.

\section{References}

1. H. Max, Irvine, "Cable Structures", The MIT Press, Cambridge, England, 1981,

2. Sir Alfred Pugsley, "The Theory of Suspension Bridges", Edward Arnold, $2^{\text {nd }}$ ed. 1968.

3. D. B. Steinman, "A Practical Treatise on Suspension Bridges, Their Design, Construction and Erection", John Wiley, $2^{\text {nd }}$ ed., 1929.

4. D.B. Steinman, "A Generalized Deflection Theory for Suspension Bridges", Transactions, ASCE, Vol.100, PP.11131170, 1935.

5. F.S. Merrit, "Structural Steel Designer's Handbook", Mc Graw- Hill Book Co., New York, USA, 1980.

6. A. Jennings, "Deflection Theory Analysis of Different Cable Profiles for Suspension Bridges", Engineering Structures, V. 9, No.2, P. 84-94 (author abstract), April 1987.

7. Colin O' Connor, "Design of Bridge Super Structures", Wiley- Inter Science, New York, P. 371-454, 1971.

8. C. Ray Wylie and L.C. Barret , "Advanced Engineering Mathematics", Mc Graw - Hill Book Co., Singapore, Fifth edition 1985.

9. T. Fukuda, "Analysis of Longitudinally Loaded Suspension Bridges", Proc. of ASCE, Vol. 94, No. ST 4, April, 1986.

10. Ahmed Gasim "Static and Free Vibration Analysis of Suspension Bridges ", PhD. Thesis ,University of Baghdad, Iraq , 1999.

11. A.R. Burden, "Modern Japanese Suspension Bridge Design", Proc. Institution of Civil engineers, Structural Engg. Part 1, paper 9654, P 157-177, Feb. 1991. 
مجلة العلوم الهندسية_العدد الثاني-2006

\section{Appendices}

a-Appendix (I)- Figures 


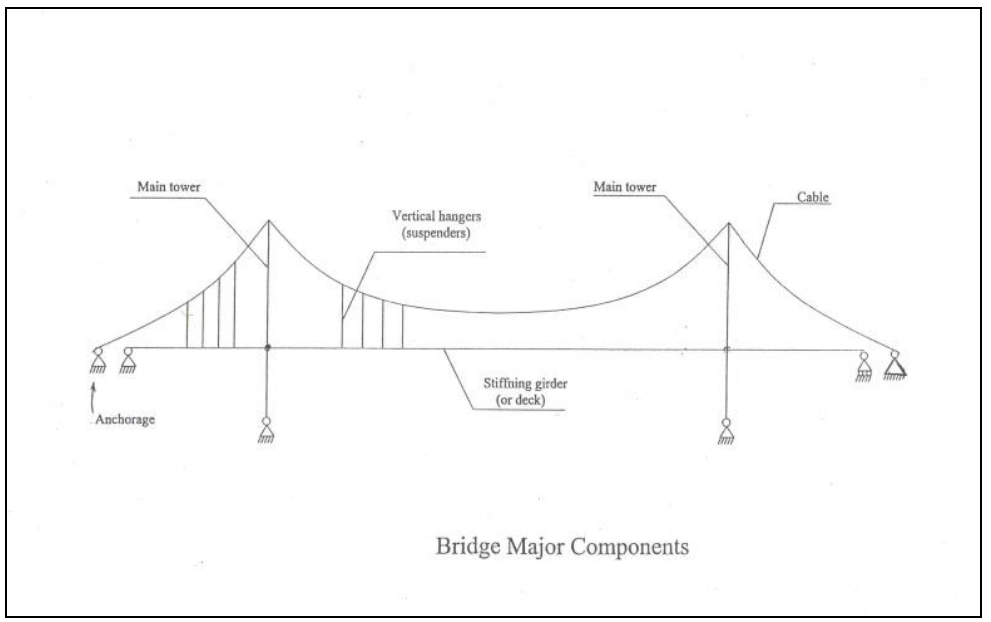

Fig (1) Bridge Major Components

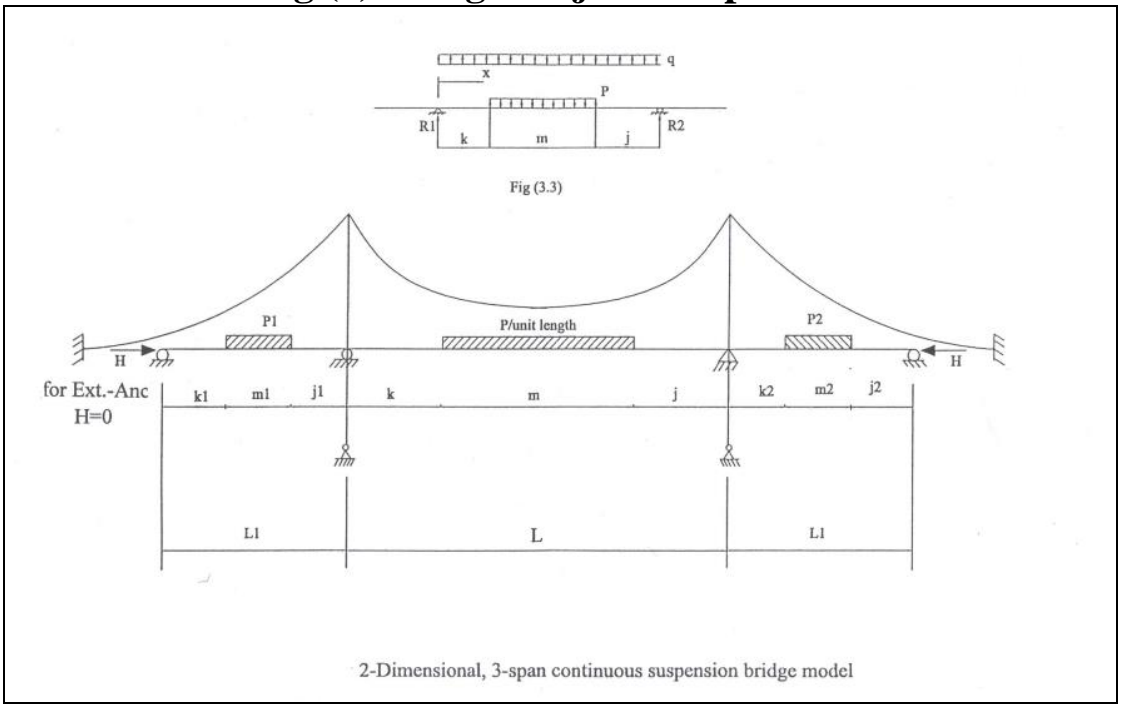

Fig (2): 2-Dimensional,3-Span Suspension Bridge Model 


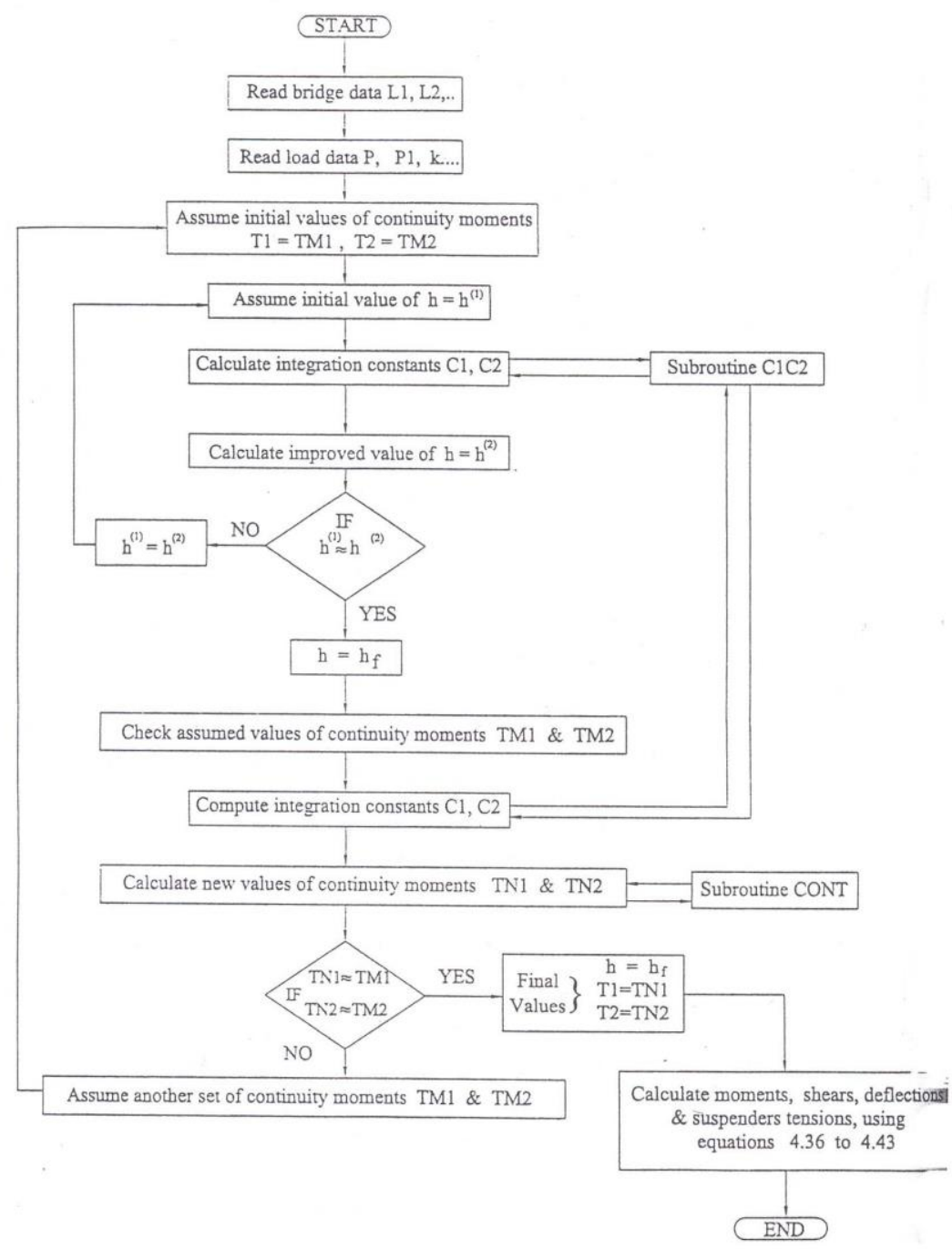

FlowChart - the deflection theory, Program SASDEF.FOR

Fig (3):- Flow Chart-Program (SADDEF) 


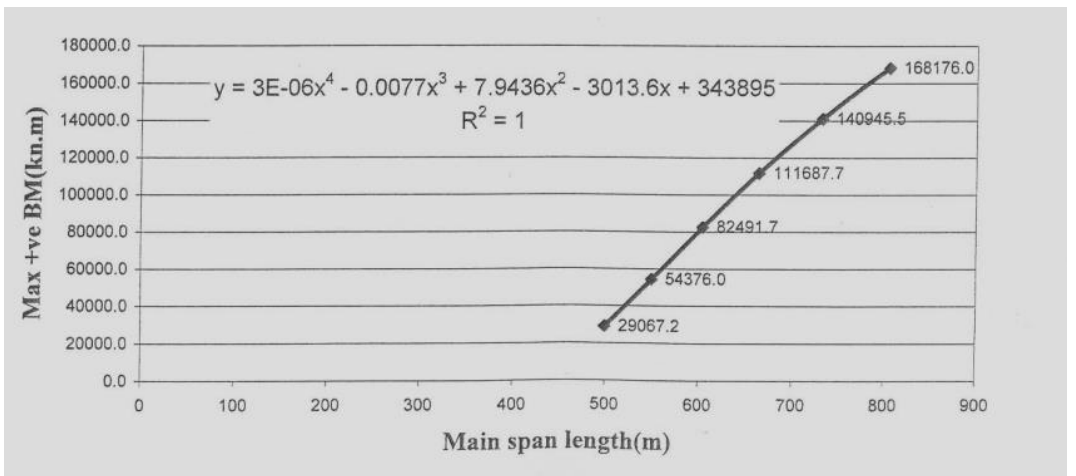

Fig (4):Max. +ve BM (kN.m) vs Main span Length,m

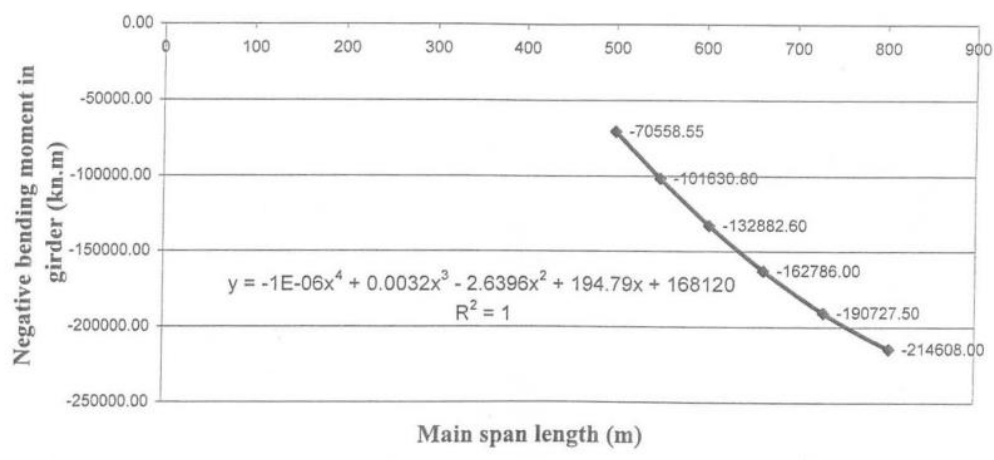

Fig (5): -ve BM (kN.m) vs Main span Length (m) 
مجلة العلوم الهندسية_العدد الثاني-2006

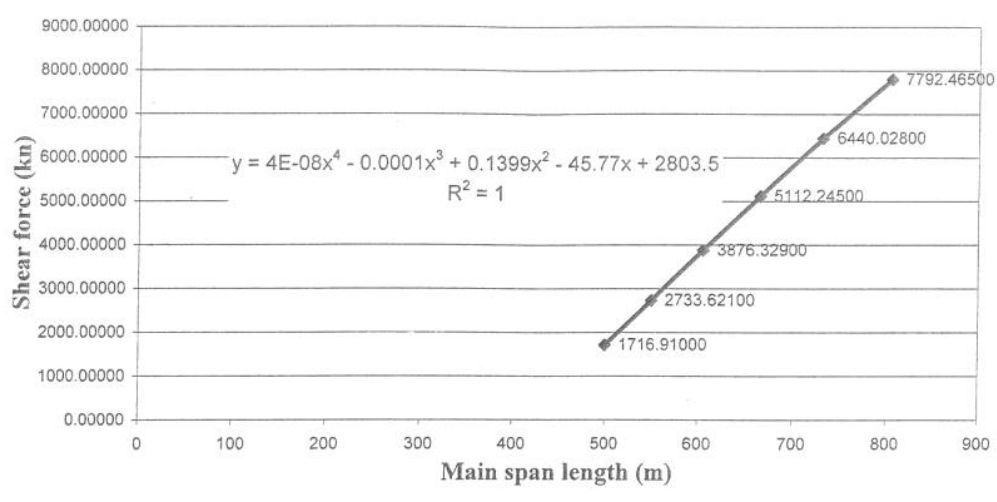

Fig (6): Shear (kN) vs Main span Length

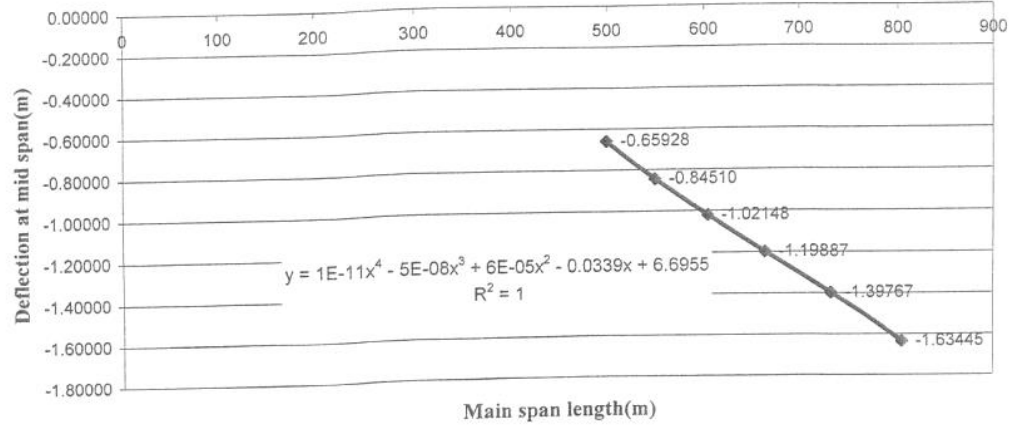

Fig (7):Max mid span deflection (m) vs. Main span Length ,m 


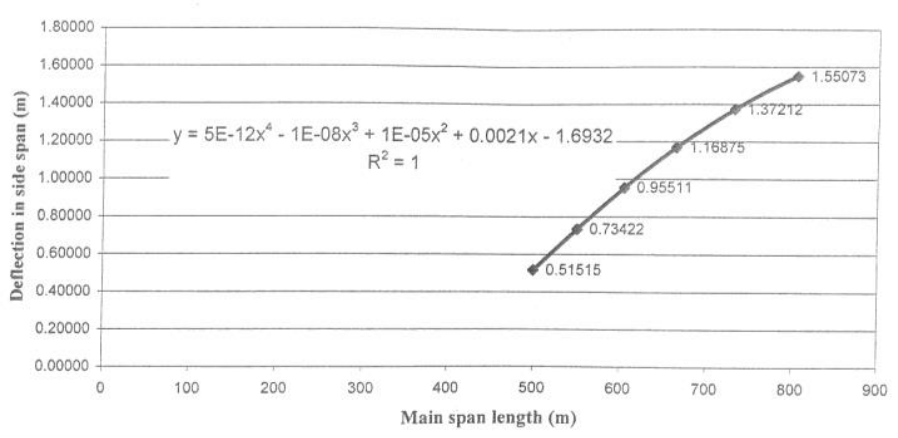

Fig (8): max Deflection in side Span vs. Main span Length

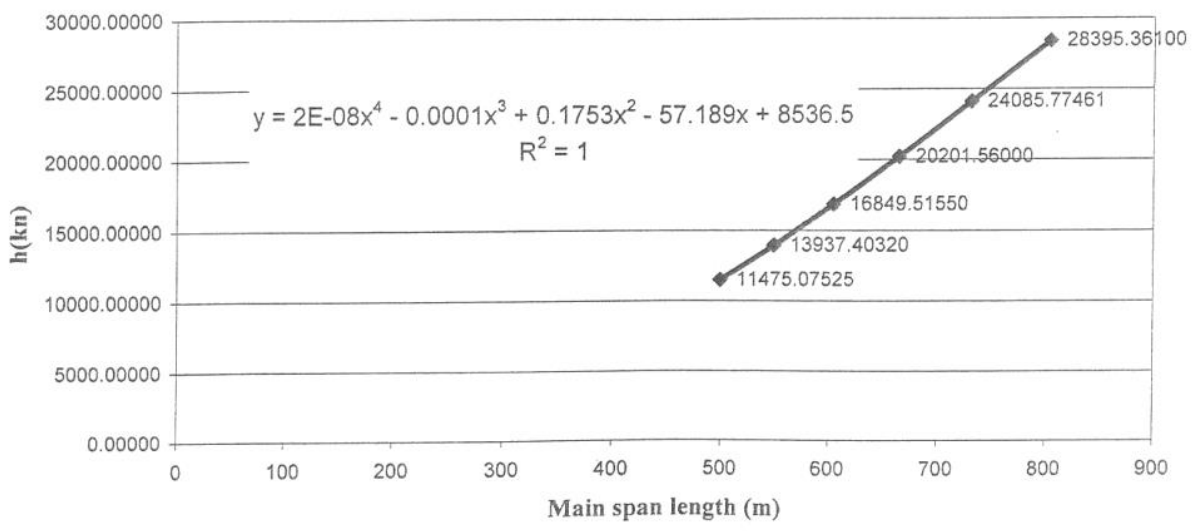

Fig (9): L.L Cable Horiz. Tension (kN) vs. Main span (m) 
مجلة العلوم الهندسية_العدد الثاني-2006

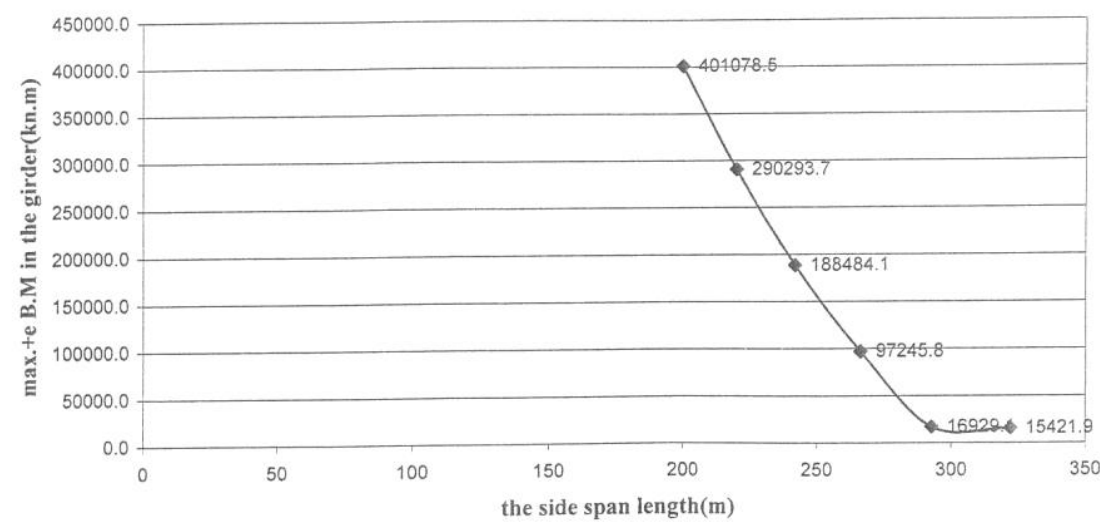

Fig (10):Max +ve BM (kN.m) vs Side span Length (m)

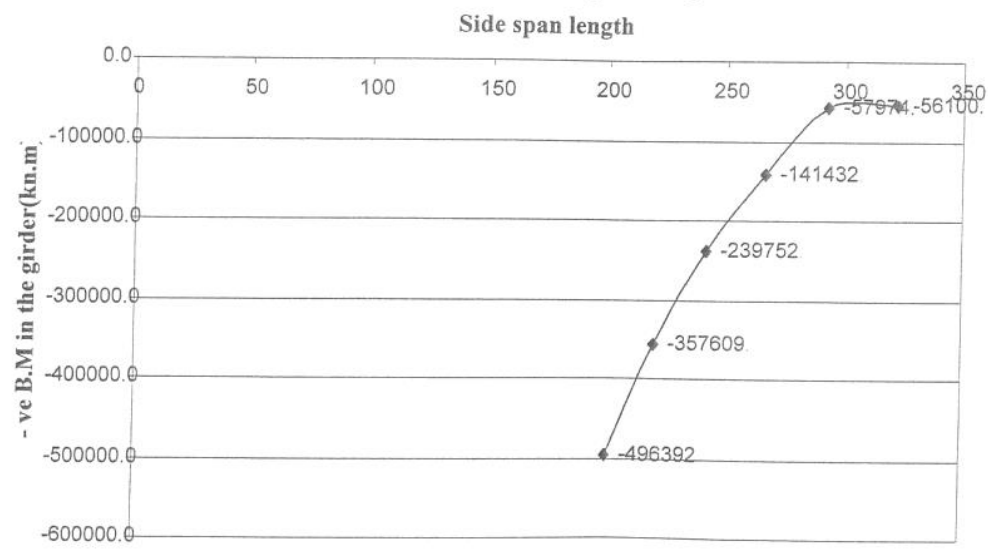

Fig (11):-ve BM (kN.m) vs. Side span Length (m) 


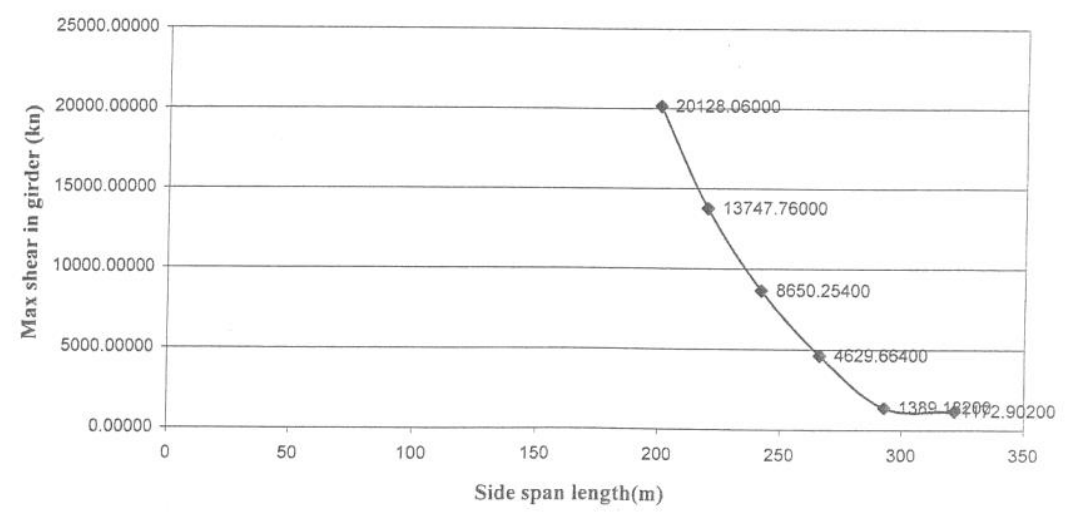

Fig (12):Max girder Shear (kN) vs. Side span length(m)

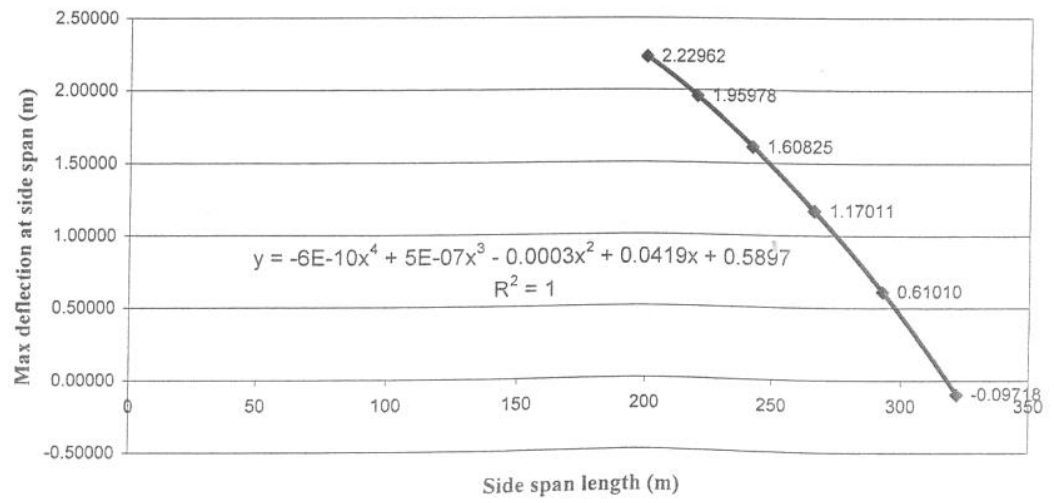

Fig (13):Max side span Deflection (m) vs. side span Length (m) 
مجلة العلوم الهندسية_العدد الثاني-2006

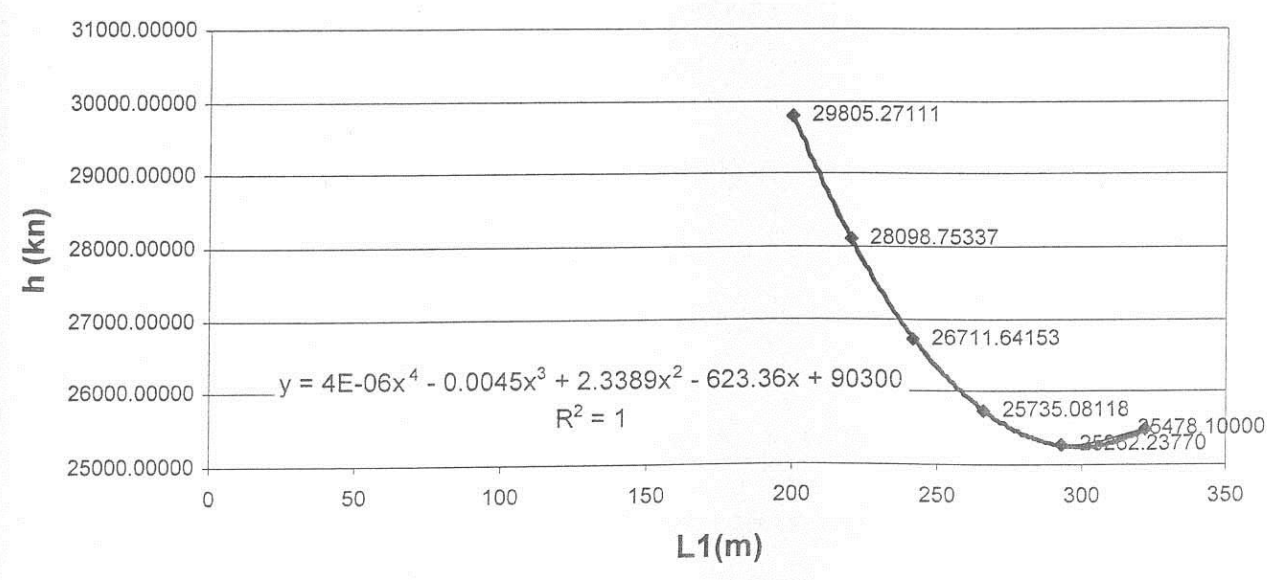

Fig (14): L.L Cable Horiz. Tension (kN) vs. side span (m)

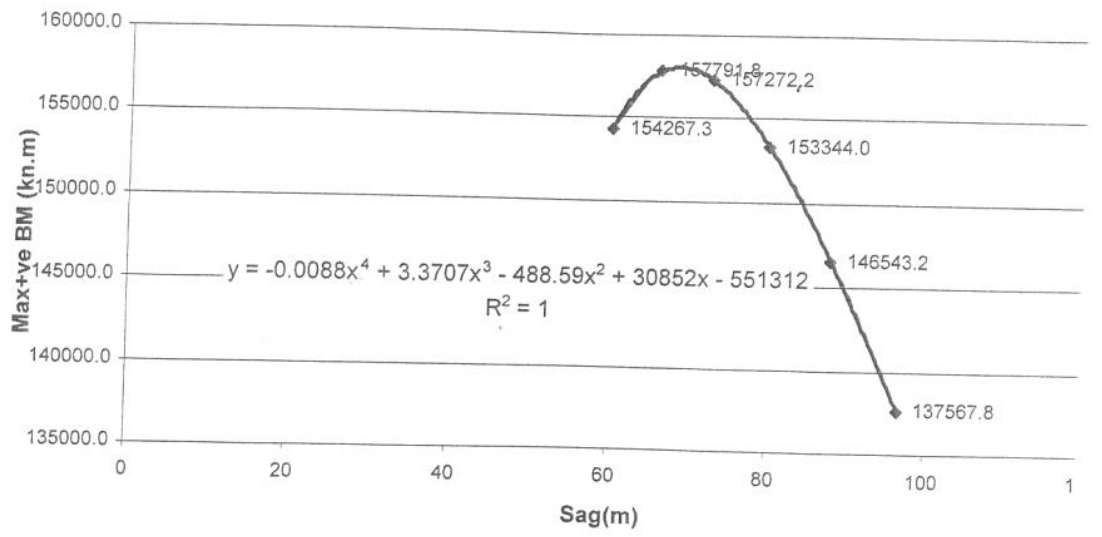

Fig (15): Max +ve BM (kN.m) vs. Cable Sag (m) 


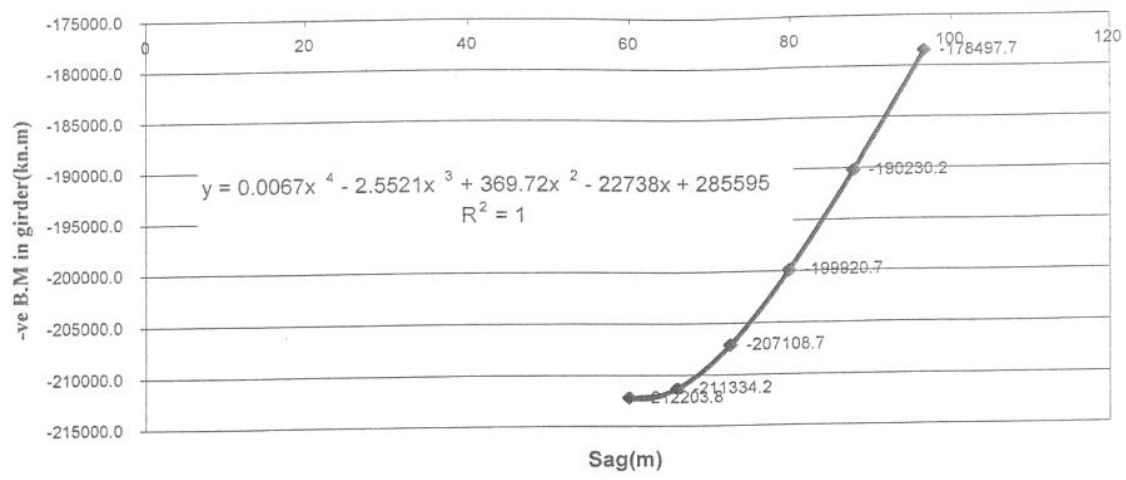

Fig (16): Max -ve BM (kN.m) vs. Cable Sag (m)

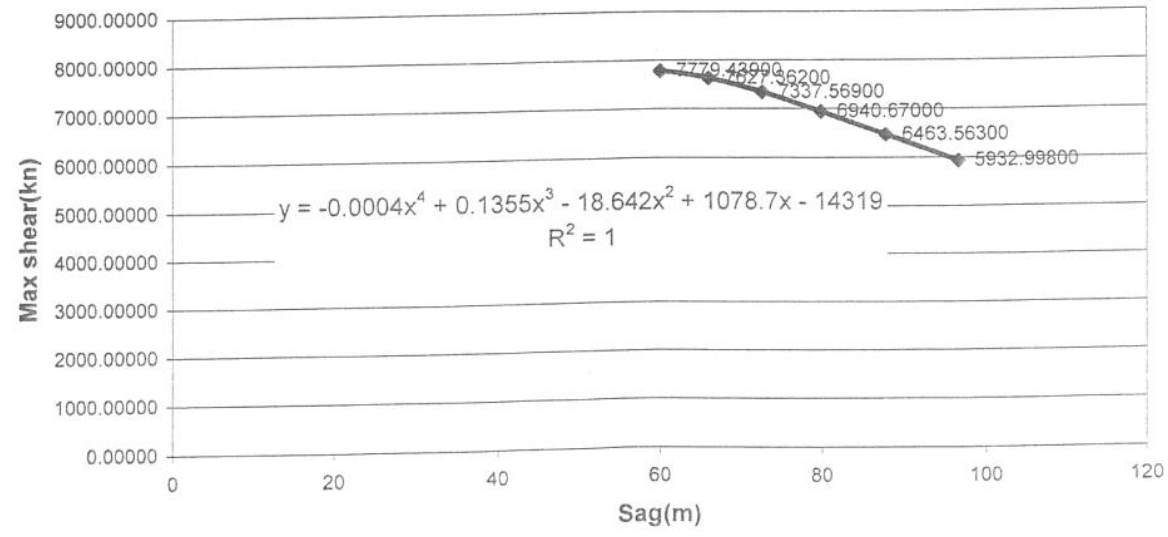

Fig (17): Max Shear (kN) vs. Cable Sag (m) 
مجلة العلوم الهندسية_العدد الثاني-2006

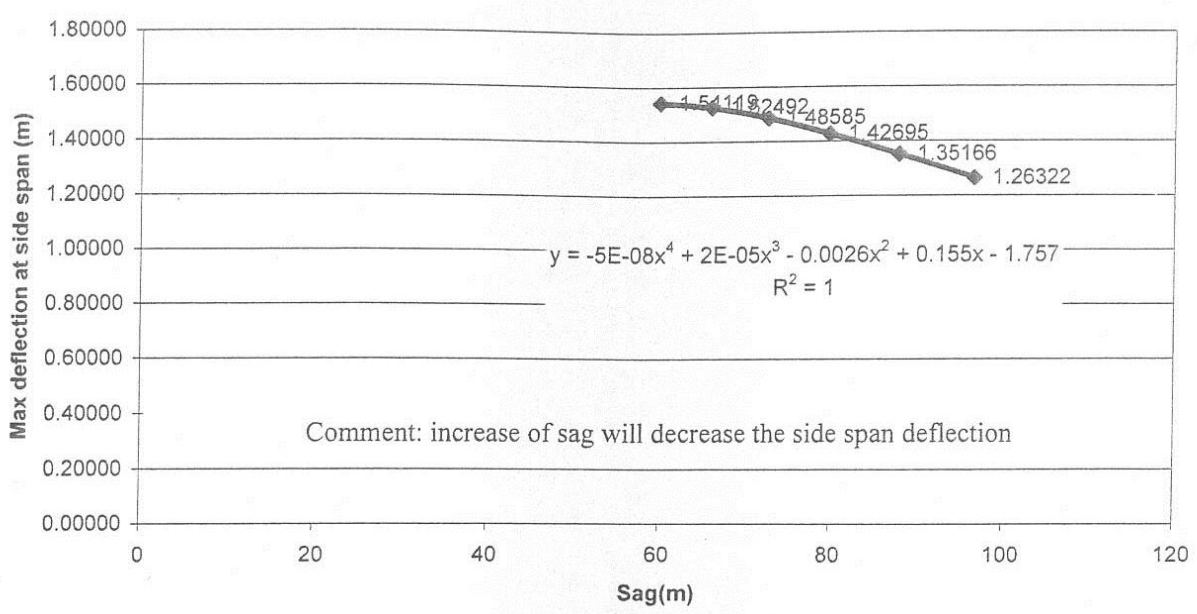

Fig (18): Max side span Deflection (m) vs. Cable Sag (m)

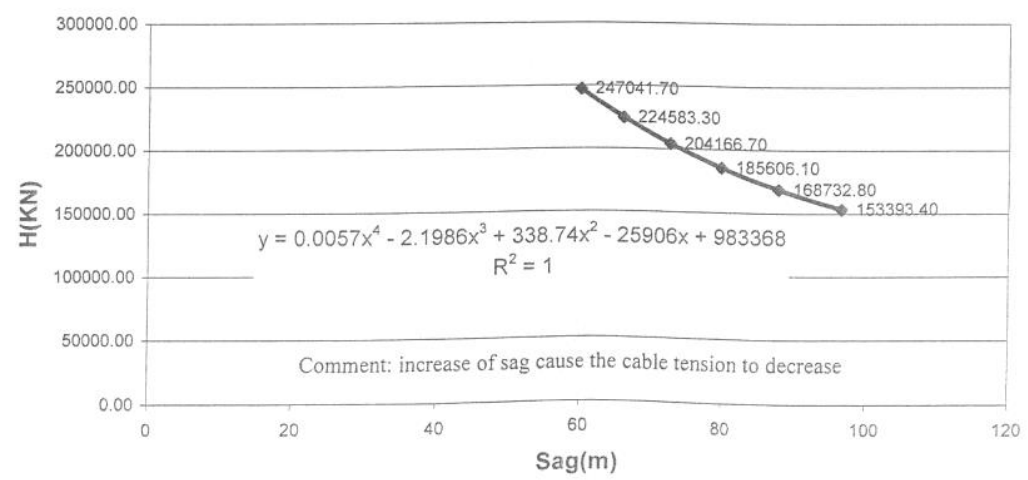

Fig (19): D.L. Horiz. Cable Tension (kN) vs. Cable Sag (m) 


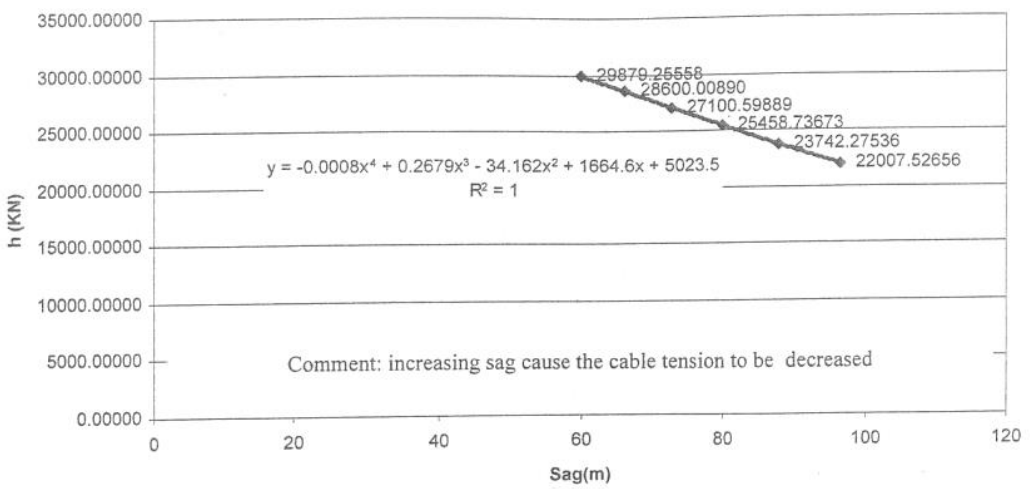

Fig (20): L.L. Horiz. Cable Tension (kN) vs. Cable Sag (m)

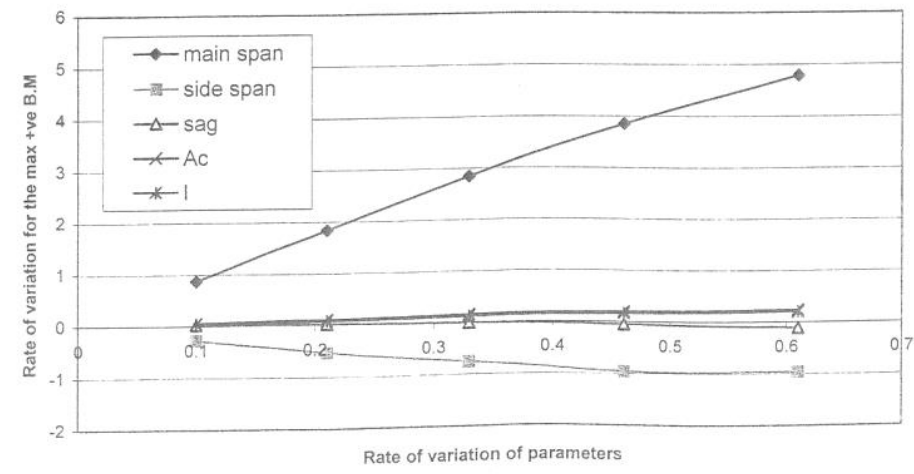

Fig (21):Max +ve BM Variation vs. Fundamental Parameters 


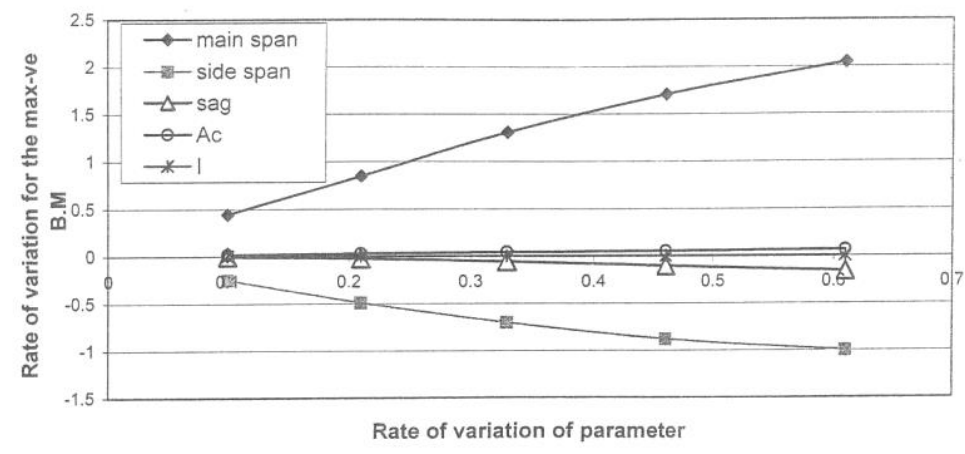

Fig (22):Max -ve BM Variation vs. Fundamental Parameters

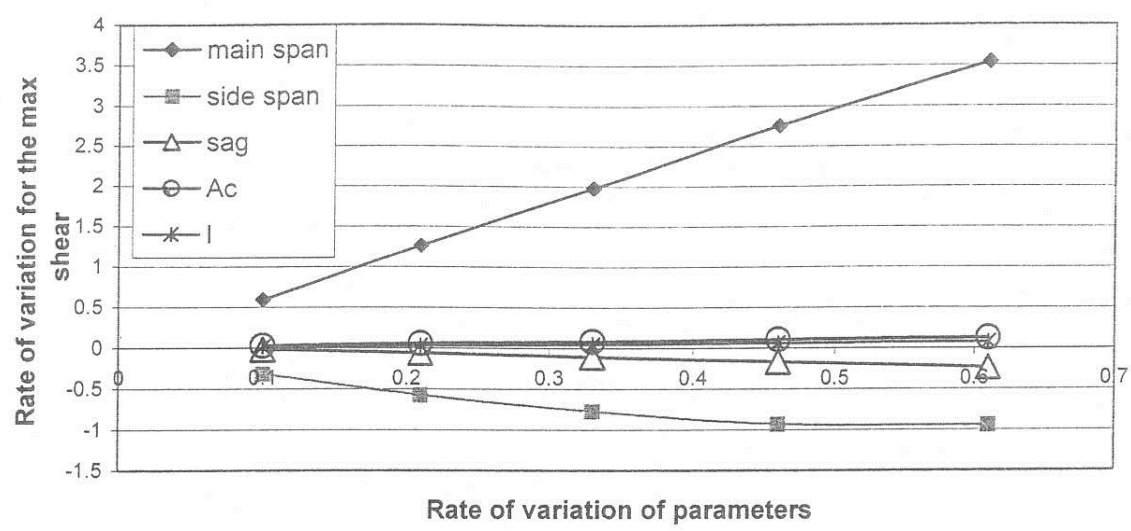

Fig (23):Max Shear Variation vs Fundamental Parameters 


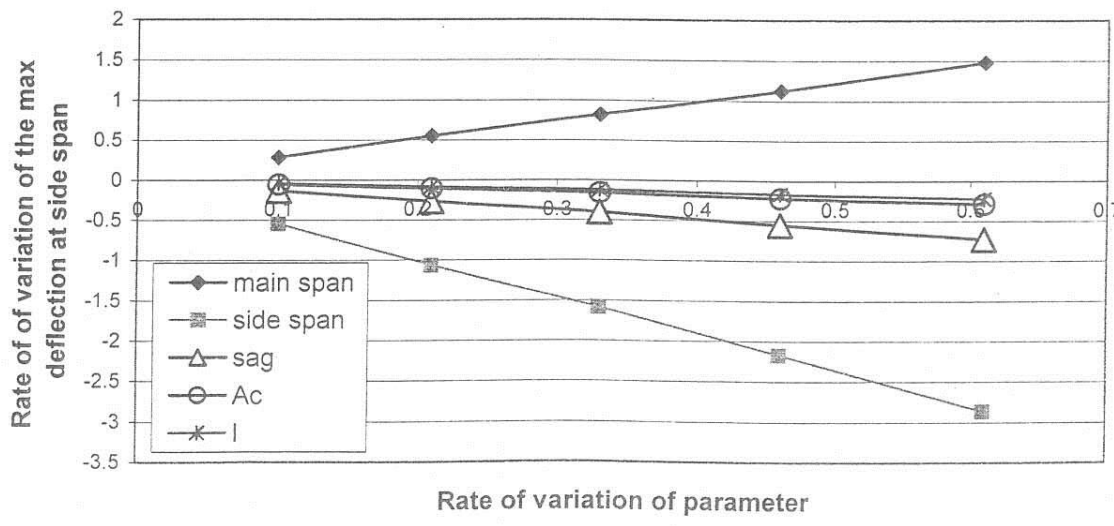

Fig (24): Max side span Deflection Variation vs. Fundamental Parameters

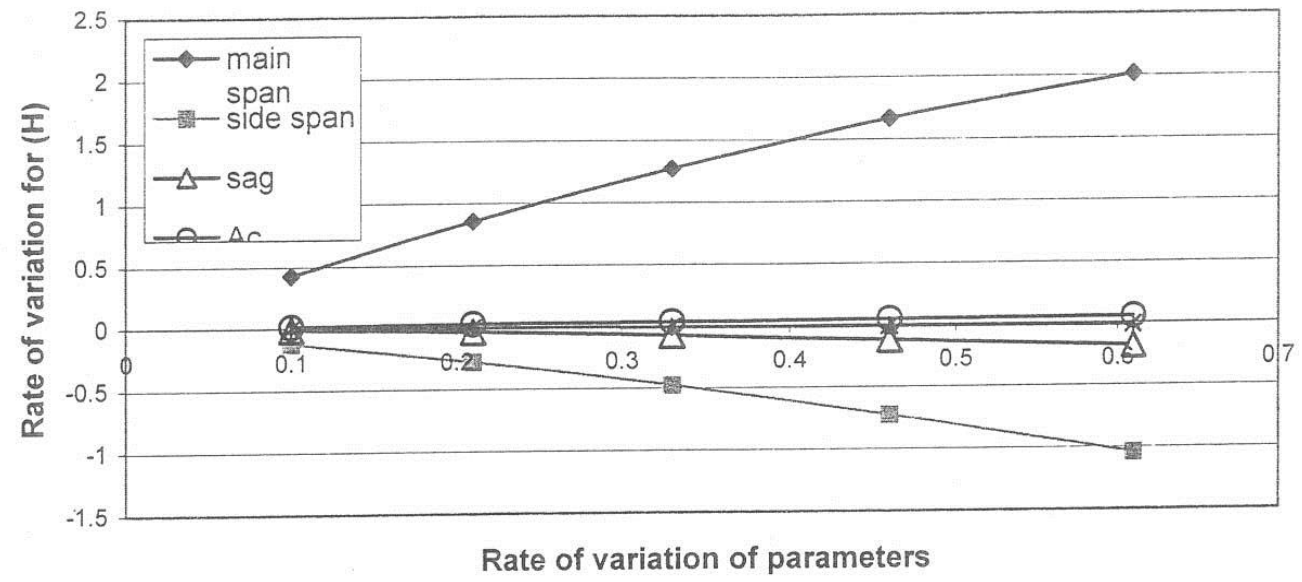

Fig (25): Initial D.L Tension Variation vs. Fundamental Parameters 
مجلة العلوم الهندسية_العدد الثاني-2006

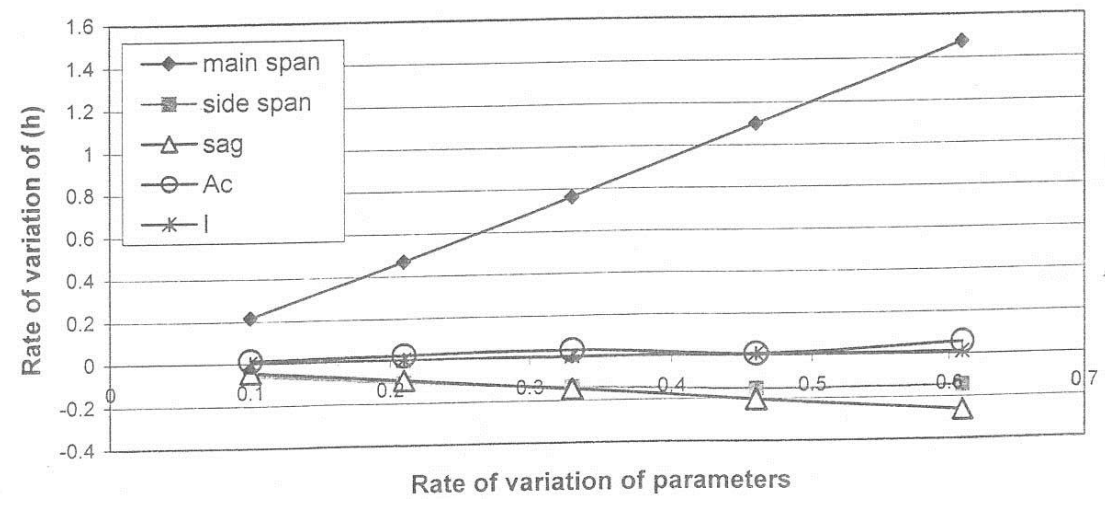

Fig (26): L.L. Induced Cable Tension Variation vs. Fundamental Parameters

\section{b- Appendix (II)- Notations}

A

Center camber of stiffening girder at mid span......

$\mathbf{a}_{1}$

Center camber of stiffening girder at side span

$\mathbf{A}_{\mathbf{c}}$

Cable x-section

$\mathbf{A}_{\mathbf{g}}$

Girder X-section

BM

Bending Moment

C1Li, C2Li

Integration Constants $\mathrm{C}_{1} \& \mathrm{C}_{2}$ on left segment of span $\mathrm{i}$

C1Mi, C2Mi

Integration Constants $\mathrm{C}_{1} \& \mathrm{C}_{2}$ on the loaded segment of span i

C1Ri, C2Ri Integration Constants $C_{1} \& C_{2}$ on the right segment of span i

d

Cable sag at mid span

$\mathbf{d}_{1}$

Cable sag at side spans

$\mathbf{E}$

Modulus of Elasticity of girder or truss 


$\begin{array}{ll}\mathbf{E}_{\mathbf{c}} & \text { Modulus of Elasticity of the cable } \\ \mathbf{g} & \text { Gravity acceleration } \\ \mathbf{H} & \text { Horizontal tension in cable due to dead load } \\ \mathbf{h} & \text { Horizontal tension in cable due to live loads } \\ \mathbf{I}, \mathbf{I}_{\mathbf{1}} & \text { Moments of inertia of the stiffening system in mid and } \\ & \text { side spans respectively } \\ \mathbf{i} & \text { Span number } \mathrm{i}=1 \text { for left span } \\ & \text { and } \quad \mathrm{i}=2 \text { for mid span }\end{array}$

$\mathbf{k}, \mathbf{m}, \mathbf{j}, \mathbf{k}_{\mathbf{1}}, \mathbf{m}_{\mathbf{1}}, \mathbf{j}_{\mathbf{1}}, \mathbf{k}_{\mathbf{2}}, \quad$ Bridge spans segments

$\mathbf{m}_{2}, \mathbf{j}_{2}$

$\mathbf{L}, \mathbf{L}_{1}$

Length of main \& side spans respectively

$\mathbf{L}_{\mathbf{c}}, \mathbf{L}_{\mathbf{c 1}} \quad$ Lengths of cable arcs on main and side spans respectively

$l, l_{1} \quad$ Cable length functions used in the cable equation

$\mathbf{M}$

Resultant bending moment at any section of girder or truss

Mo Simple beam bending moment due to live load

$\mathbf{P}, \mathbf{P}_{1}, \mathbf{P}_{2} \quad$ Uniform applied live loads on midspan, left span and right side span respectively

$\mathbf{P}_{\mathbf{g}} \quad$ Part of the live load carried by the girder

$\mathbf{q}, \mathbf{q}_{1}, \mathbf{q}_{2} \quad$ Live load carried by the cable on mid, left $\&$ right spans respectively

$\mathbf{R}_{\mathbf{1 i}}, \mathbf{R}_{\mathbf{2} \mathbf{i}} \quad$ Simple beam end reactions at girder supports of span I 
$\mathbf{T}$

$\mathbf{T}_{1},-\mathbf{T}_{2}$

$\mathbf{t}$

$\mathbf{U}_{1}, \mathbf{U}_{2}$

V

$\mathbf{v}, \mathbf{v}_{1}, \mathbf{v}_{2}$

$v^{\prime}, v_{1}^{\prime}, v_{2}^{\prime}$

$\mathbf{w}$

$\mathbf{x}, \mathbf{x}_{1}, \mathbf{x}_{2}$

$\mathbf{y}, \mathbf{y}_{1}$

$\mathbf{z}, \mathbf{z}_{1}$

$\theta, \theta_{1}$

$\alpha$
Bending moment at any section, $\mathrm{x}$, due to continuity

Bending moments in the girder at left and right supports respectively

Temperature change

Slope-change functions at towers

Total vertical shear at any section, $\mathrm{x}$, of the girder or truss

Deflection of the girder or truss at any section in mid, left, and right spans respectively due to live loads Slope of the deflected shape of the girder or truss at any section in mid, left, and right spans respectively

Uniformly distributed dead load on the cable

Abscissas on mid, left and right spans respectively measured form right end of each span

Cable ordinates on main and side spans respectively

Stiffening girder ordinates on main and side spans respectively due to camber

Slope of cable chord in mid \& side spans respectively

Coefficient of thermal expansion 